\title{
A DIFFERENT APPROACH TO THE RELATION BETWEEN IMPORTS AND INFLATION FOR TURKEY: DUTCH DISEASE ILLUSTRATION
}

\author{
DOI: 10.17261/Pressacademia.2019.1114 \\ JEFA- V.6-ISS.3-2019(5)-p.159-169
}

Rıdvan Karacan ${ }^{1}$, Vedat Cengiz ${ }^{2}$, Zisan Yardim Kilickan ${ }^{3}$

${ }^{1}$ Kocaeli University, Department of Economics, Hereke Vocational School, Marshall Campus, Kocaeli, Turkey. karacanr@gmail.com, rkaracan@kocaeli.edu.tr, ORCID: 0000-0002-4148-0069

${ }^{2}$ Kocaeli University, Faculty of Economics and Administrative Sciences, Umuttepe Campus, Kocaeli, Turkey. vcengiz@kocaeli.edu.tr, ORCID: https://orcid.org/ 0000-0001-7010-4380

${ }^{3}$ Kocaeli University, Faculty of Economics and Administrative Sciences, Umuttepe Campus, Kocaeli, Turkey. zisany@yahoo.com, ORCID: 0000-0002-2962-3565

Date Received: June 21, 2019

Date Accepted: September 18, 2019

\section{To cite this document}

Karacan, R., Cengiz, V., Kilickan, Z.Y., (2019). A different approach to the relation between imports and inflation inTurkey: Dutch disease illustration. Journal of Economics, Finance and Accounting (JEFA), V.6(3), p.159-169.

Permemant link to this document: $h$ ttp://doi.org/10.17261/Pressacademia.2019.1114

Copyright: Published by PressAcademia and limited licenced re-use rights only.

\begin{abstract}
Purpose - The adverse circumstances which have been experienced in Turkey's economy recently are attributed to different justifications. One of these is the case defined as 'Dutch Disease' in literature. Dutch disease is an economic term for the negative consequences that can arise from a spike in the value of a nation's currency. Within this context, it has been desired to test the validity of 'Dutch Disease' in Turkey's economy for the 2002-2018 period. The case that there is no research which is put forward recently or made with a similar method makes the study different from the others.

Methodology - In the study, it is used the annual data belonging to the variables of Consumer Price Inflation (CPI) and Imports between the years 2003-2018. Empirical analysis has been executed by using SPSS (22) Pearson's Test technique and Regression Analysis.

Findings- According to the obtained findings, contrary to what is alleged, there is no connection of the adverse circumstances which have been experienced in Turkey's economy recently to 'Dutch Disease'.

Conclusion- For the Dutch Disease to be able to occur, the currency used as medium of exchange is required to be convertible. Because the national currencies of the developing countries such as Turkey are not convertible, the national currency appreciates only within the boundaries of the country. The decrease of the production in Turkey is associated with imports not becoming cheaper but on the contrary becoming more expensive.
\end{abstract}

Keywords: Turkey, Dutch disease, SPSS Pearson's test, regression analysis.

JEL Codes: C18, E20, E40

\section{INTRODUCTION}

When the national currency loses in value, the prices of exports cheap and imports become more expensive. If the national currency increases in value, the reverse situation. Namely, imports become cheaper and exports become more expensive. Imports becoming cheaper in that way can especially attract the attention of domestic manufacturers. In such cases, the manufacturers tend towards purchasing cheaper ready stock from abroad rather than taking the risk of production. It is a fact known by almost everyone that importers need foreign currency to be able to import. In an economy where the national currency increases in value, the entrepreneurs who can obtain the opportunity to be able to buy more foreign currency at every turn with the savings in their hands make contribution to nation's money supply on one hand and restrict foreign exchange supply on.

Besides, this also means that the exportation incomes will decrease after exports becoming more expensive. The foreign exchange bottle-neck can occur by the importer's hand on one side and the exporter's hand on the other side. In other 
words, this situation which means the loss in value of national currency might be a cause for the phenomenon of inflation (Altınok and Çetinkaya, 2003:55).

The notion 'Dutch Disease' was used for the first time in 1960s after Holland discovered such huge natural gas sources in the North Sea that the competition was affected negatively (Yiğit, 2001:2). After the discovery of natural gas sources, Holland's national currency gained value (Weijermars and Luthi, 2011:3-14). Therefore, Holland lost its competitive power; while public sector develops, the profitability of secondary sector decreases and the production resources are directed to service sector. All these cause the industrialization to regress (Adenauer and Vagassky, 1998:177-185). Similar conditions were experienced in 1970s when the crude oil price increased significantly in Great Britain. The effect of this progress led to England becoming a clear petroleum exporter and therefore British Pound gained value. The argument whether 'Dutch Disease' is a notion which is required to be taken into consideration just by countries or a form of progress is still ongoing (Nchor, et al. 2015:2035).

We can identify the three paradigmatic conditions of the prevalence of Dutch Disease: the discovery of natural sources which benefits from Ricardian rentals taking place in a poor country and damages to the industrialisation of this country; the same discovery which causes to the period of industrialisation and leads to not to be neutralized in a rich country; and eventually, both commercial and financial radical liberalization of country's external accounts; and this leads to leave the policies which neutralise Dutch Disease and early industrialisation (Brahmbhatt, et al. 2010: 1-7). The first case is the situation of Arabia, Venezuela and other poor countries; the second is the situation of Holland and the United Kingdom; the third one is seen in Brazil, Argentine and Mexico. The first case exists every time and Indus prevents (Pereira, 2013:378).

There were lots of precautions to be implemented for some structural reforms as part of Transition to the Strong Economy Program recommended by IMF after 2001 crisis in Turkey (Değirmen, 2008:134). Among these precautions were principles such as restructuring of the banks and general finance sector, establishing of BRSA (Banking Regulation and Establishing Supervision Agency) and renewing the financial sector's place at the top (Kesebir, 2018: 1-19). Thereafter, the expenses have decreased and the issue of taxable losses was solved and therefore, the budget deficit has been reduced with the purpose of providing the fiscal discipline of public sector (Okutan, 2015:1162). When the budget deficits reduced, public borrowing reduced and inflation and interest rates started to decrease. In this period, the value of TL has increased (Karagöl and Erdoğan, 2017: 367). Afterwards, the negotiations of full membership with the European Union have been started and six zero from the currency unit has been removed. Therefore, the entrance of foreign exchanges to Turkey has accelerated by increasing the trust on TL. As a result of these developments, TL has extremely gained value in comparison to foreign currency units. The extreme value of TL has encouraged imports and restricted exports. A great deal of industrialists has left the manufacturing and become importer. Everywhere has gotten full with cheap imported goods (Eğilmez, 2019).

The developments which have been seen in Turkey's economy in this period are likened to 'Dutch Disease'. The improvements which were realized in the economy previously and the revaluation of national currency and thereafter the rise of the inflation to double-digits and the increase of imports have been effective for this metaphor. In the light of all these facts mentioned, a study is made with the purpose of replying to the question "Is there Dutch Disease in Turkey's economy?" For this, the annual data belonging to the variables of Consumer Price Index (CPI) and Imports between the years 2003-2018 is used. Empirical analysis has been executed by using SPSS (22) Pearson's Test technique. The data belonging to the study are taken from the sources Turkish Statistical Institute (TSI) and the Central Bank of the Republic of Turkey (CBRT).

The article main parts are the abstract, introduction, method, results, discussion, and references. The introduction consists of an opening that presents the research question, a literature review that describes previous research on the topic, and a closing that restates the research question and comments on the method.

\section{THEORETICAL FRAMEWORK OF THE RELATION BETWEEN THE VALUE OF NATIONAL CURRENCY AND INFLATION IN TURKEY}

Inflation rates are an indicator whether the national currency increases in value, because there is an inverse proportion between these two variables. According to this, rising of the inflation rates means the depreciation of national currency; declining of the inflation rates means the appreciation of national currency (Rojas-Suarez, 1992; Savastano, 1996; RamirezRojas, 1985:629). Considering this fact, in the study, the value of Turkish Lira is evaluated based on the inflation rates. The depreciation of national currency means the purchase of fewer goods and services with more amount of money; so, this situation is stated as the phenomenon of inflation in literature. 
In literature, Irving Fisher, the famous economist, explains the relation between the inflation and the value of national currency with the equation of Quantity Theory of Money. Irving Fisher, American economist, gives place to his theory in his book named "The Purchasing Power of Money" (Fisher,1911).

The equation expressed as Fisher's Quantity Theory is as follows;

$M . V+M^{\prime} . V=P . T$

Here;

M: The amount of money in circulation,

$\mathrm{V}$ : the circulation speed of the money, $\mathrm{M}$ ': the amount of the bank money,

$\mathrm{V}$ : Circulation rate of the bank money, P: General level of prices,

$\mathrm{T}$ : Indicates the process volume.

According to Fisher, the variables $\mathrm{V}$ and $\mathrm{T}$ in his equation are fixed and don't change during a certain period. Nevertheless, the amount of $\mathrm{M}$ (Money Supply) which takes place in equation might change. Depending on the change of $\mathrm{M}, \mathrm{P}$ which is on the right side of the equation and is defined as general level of prices will change in the same direction. In such a case, the increases in the amount of money will directly lead to rise of the general level of prices and the depreciation of money (Fisher, 1911:87-88).

The inflation which became chronic in Turkey's economy till 2000s has gradually declined to one-digit numbers after 2002 with the "Transition to the Strong Economy Program" after the crises of November 2000 and February 2001 (Taşar, 2010:94-95). It is surely beyond doubt that the contribution of both internal and external factors in the success of this program is significant. Including this period, domestically, the country which was ruled by coalitions for many years has attained a single-power stability in the sense of ruling. In the same period, abroad, the positive economic conditions which have been seen globally have a significant contribution in the stability attained.

The strategy of "inflation targeting" has been used as the tool of monetary policy in fighting against inflation since 2002. Within this framework, the implicit inflation targeting was executed between the years 2002-2005, and the open economy inflation targeting has been executed since 2006 (Durmuş, 2018:181). In the first four years of inflation targeting, inflation realizations stayed under the determined inflation targeting. However, together with the transition to the open economy inflation targeting, the inflation rate which realized during three years after 2006 exceeded the target rates (Uğurlu and Saraçoğlu, 2010: 70). The inflation rates which stayed under the target in the period of 2009-2010, have been exceeding the target since 2011. Although the inflation target was determined as 5,5\% in 2011, the inflation in 2011 was realized in excess as $10,4 \% .7,5 \%$ is the maximum rate. The inflation target which was determined as $5 \%$ in the period of 2012-20132014 couldn't be realized with the rates 6,2 \% in 2012, 7,4\% in 2013 and 8,2\% in 2014 (Sungur, 2015:253-254).

Both the implicit inflation and the open economy inflation targeting strategy were execeuted between the years 2002-2016 in Turkey. The realizations in inflation were only under the target between the years 2009 and 2010 and between the range of the target in 2012 (Güney and Ceylan, 2014: 153-154). The realizations which occurred in other years stayed out of the range of the target. It can be stated that the inflation was about $10 \%$ between the years $2006-2016$ in Turkey (Öztürk and Usanmaz, 2018: 98).

The consumer price inflation which exhibited a gradual slowdown trend, realized 7 percent in November 2016 and near to the lower limit of October Inflation Report estimates. However, inflation in December completed the year above the estimates with 8,53 percent by increasing significantly with the effect of the fluctuation in unprocessed product prices and tobacco price adjustments (CBRT, 2017).

Similarly, the consumer price inflation was realized above the upper limit of estimates with 11,29 percent in March, 2017. The effect of the increase in food prices was felt, as well as the depreciation in Turkish Liras and the increase in the import prices in upper- directional course of inflation. Especially the effects of the depreciation in Turkish Liras spread to the whole index. 2017 Consumer Price Inflation was realized as 11,20 percent in September and above the estimates of July Inflation Report. Annual inflation went beyond the estimations in the core indicators with the effect of the depreciation in Turkish Lira versus Euro and the strong course in economic activity in the energy group as well as the increase in the prices of petroleum and other inputs in this period (CBRT, 2018).

Consumer price inflation was realized in accord with the estimates of January Inflation Report with 10,23 percent by decreasing 1,69 points in comparison to the end of the previous quarter, in the first quarter of 2018. Consumer price inflation went beyond estimations with 15,4 percent and 24,5 percent respectively in the second and third quarters of 2018. Consumer price inflation realized under the estimates of October Inflation Report with 20,30 percent by decreasing 
4,2 points in comparison with the end of the previous quarter in the last quarter of 2018. In the occurrence of this situation, together with the other variables, the weak course of depreciation in Turkish Liras became effective (CBRT, 2019).

\section{THE RELATION BETWEEN THE VALUE OF NATIONAL CURRENCY AND IMPORTS}

In the case of depreciation of national currency, while the import prices become cheaper, the export prices increase. In the case of appreciation of national currency, a reverse situation is valid, as well (Ordu, 2013:65). Briefly, the appreciation of national currency is defined as increasing the amount of foreign currency at every turn that a unit of national currency can purchase. Assuming that the prices of goods subject to import trade don't change, importers obtain the opportunity of being supplied more foreign exchange in exchange for the national currency in hand at every turn. (Coşkun and Taylan, 2009: 160). This also implies increasing the amount of goods that the importer can purchase. In such a situation, by taking into consideration the hypothesis that the domestic demand will also increase, the amount of goods which is subject to import will increase much more. Surely, this is not a sustainable situation in the long run. Likewise, the currency loss increasing in that way will lead to the collapse of the country's balance of international payments. Certainly, this is valid assuming that exports and other foreign exchange earning items don't increase.

In literature, the relation between the value of national currency and foreign trade is stated by "Foreign Trade Movements Approach". According to this, the value of a country's national currency changes depending on this country's exports and imports. In case that imports are more than exports, the national currency will depreciate. In the reverse situation, the national currency will appreciate (Karaçor and Gerçekler, 2012: 293; Ünsal, 2005: 543-548). Therefore, all factors affecting the exports and the imports of the country also affect the exchange rate appreciation or depreciation (Tapşın and Karabulut, 2013:190). Among these, the factors such as the relative prices of domestic and foreign items, the real income increases in internal and external economies, consumers' preferences and technological progress can be regarded (Hyder and Shah, 2004). Although, according to this approach, while it is required that the national currencies of the countries whose balance of international payments has a deficit depreciate, there is mostly no depreciation seen but an appreciation in the national currencies of countries in that case. This situation results from the fact that "Foreign Trade Movements Approach" ignores the effect of capital flows in exchange rate adjustments (Seyidoglu, 2007:418).

While the current account deficits enter into the growth process as a result of extreme appreciation of national currency; the cost of closing public deficit as a result of the increase in interest rates also increases (Orhan and Nergiz, 2014: 158). By decreasing investment and manufacturing, this situation leads economies to turn into a structure where financial transactions are predominant (Wicksell, 1962:7-15). With the unrestrained liberalization of national finance markets within this context, national economic policies turn into a structure which controls just the capital flows instead of providing macroeconomic stability and growth. This also decreases the output and employment capacity of the country (Başoğlu, 2000: 95-97).

The extreme difference in the value of national currency unit against foreign currency units for different purposes in Turkey caused a significant effect on its economy. With the transition to flexible exchange rate system in 2001, the increase in real exchange rates has become evident (Okur, 2002:43). For this reason, structural transformations have been implemented in the manufacturing and foreign trade sectors. While the dependency ratios of manufacturing and exportation to importation increase, it is ascertained that the output growths are realized in the sectors which have relatively high technology and depend on imports (Taymaz and Voyvoda, 2015: 25-62). Similarly, the capitalisation per employee in the manufacturing industry has increased and therefore the labour-capital ratio decreases in favour of capital (Şimşek, 2017: 79). It is ascertained that the business corporations which operate in manufacturing industry supply their financial need by the way of foreign currency-denominated borrowing predominantly and this also increases the dependency of imported inputs (Kundak and Aydoğuş, 2017:264). These developments which prepare high real exchange rates weaken the relation between the current output and employment in manufacturing industry (Balaylar, 2011:117).

\section{LITERATURE RESEARCH}

Standford (2012) - In his study, he points to the symptoms of 'Dutch Disease' for Canada's economy recently. These symptoms are such: by increasing the petroleum production especially, exports and oil sands expand significantly. Thereafter, manufacturing and employment decreased drastically. From the beginning of the century, approximately 600.000 Canadian manufacturing works have disappeared. Canada's currency unit has dramatically appreciated $60 \%$ against the US dollar denomination. The general trade balance of Canada has collapsed. Standford has mentioned the mandatory precautions to be taken about investing to progressive and modernist industries to address this unfavorable situation.

Pereira (2013) has made a study which states the importance of exchange rate within the context of Dutch Disease for the economies of Mexico, Chile and Norway. She has revealed that the depreciation of national currency to get rid of this 
negative situation is difficult. Instead, a powerful progress coalition is required to carry the exchange rate to the level of industrial balance and to keep it at this level.

Brahmbhatt et al. (2010) - He has made a research regarding solutions to a possible Dutch Disease problem across the world. Within this context, it is suggested to revise the spending policies, giving priority to the investments such as transportation, logistics and substructure with the purpose of directly attracting foreign investors, building rural roads to decline the poverty especially in low income countries and prioritizing public projects.

Nchor et al. (2015) - He has made a study testing Dutch Disease for Ghana's economy. Given the criteria stipulated for measuring the presence of the Dutch Disease, the analysis shows that the real eff ective exchange rate in Ghana depreciated generally. At the same time, the study points that a permanent effect doesn't occur in real effective foreign exchange rate since the beginning of commercial petroleum production which is an indicator of existing the phenomenon 'Dutch Disease'.

Botta et al. (2015) - He has made a study for Colombia's economy. According to this, he has stated that there have been downsizings especially in the manufacturing industry after a while in Colombia which has rapidly entered into the growth process. This situation which is characterised as Dutch Disease has distinguished itself with the massive increase in mining exports firstly and then the appreciation of national currency. He has suggested that it is required for the government of Colombia to encourage domestic manufacturers and to implement policies which vary the exports base to a great extent regarding the solution of the problem.

Sy and Tabarraei (2010) - It's theoretically and empirically revised the connection between capital inflow and real exchange rates movements in developed countries. According to this, while Balassa-Samuelson effect constitutes $57 \%$ of the change of real exchange rates by itself, capital inflow constitutes just $19 \%$ of. Theory of Dutch Disease isn't denied, however, its effect on external debts and real exchange rates movements is weak.

Kenell (2008) - In his study, Kenell points out that the tourism industry in Thailand draws the resources into tourism sector from the other sectors of economy, and in this way, leads to industrialization by damaging Thailand's international competitiveness. An empirical study has been analysed according to the theory of Dutch Disease. The theory envisages that real exchange rate will appreciate as a result of foreign capital inflow in massive amounts. Accordingly, tourism sector has also a significant share for total Gross Domestic Product (GDP). Nevertheless, according to the researches which are done for this thesis, it's seen that it doesn't lead to Dutch Disease.

Mercan and Göçer (2014) - Hypothesis of Dutch Disease is tested by using the method of Panel Data Analysis with the data of the period 1990-2011 for Central Asian Turkish Republics. In the result of analysis, it is defined that the increase in the prices of petroleum in these countries affects the real exchange rate negatively and the hypothesis is not valid.

Akça and Bal (2017) - A study is made with the purpose to ascertain whether workers' remittances lead to a real appreciation in the home country's currency by using panel data for the period of 1990-2014 belonging to 9 countries selected among the countries receiving Workers' Remittance. Findings obtained from the analysis with the two-way random effects estimation suggest that, as a Dutch Disease Symptom, Workers' Remittances lead to a real appreciation of the home countries' currencies.

Destek et al. (2017) He has made a study for Azerbaijan, Kazakhstan, Kyrgyzstan and Uzbekistan economy for the period 1991-2013. The concluded that Dutchdisease is valid in Azerbaijan. It is inferred that the prosperities obtained from the natural resources are efficiently used in Kazakhstan and Kyrgyzstan, but there is no relationship between oil rents and agricultural added value in Uzbekistan.

Arı and Özcan (2012) - It is investigated whether workers' remittances cause Dutch Disease problem or not. As a result of the study where the methods of fixed effect and instrumental variable from Panel Data Models are utilised, the proof is reached which affirms the existence of Dutch Disease.

Akçacı and Karaata (2014) - An empirical study is made of the causality relationship among the portfolio investments of the period of 2006-2013 and industrial production index and exports regarding the existence of Dutch Disease for Turkey's economy. The obtained findings points that the portfolio investments cannot be evaluated as a variable which leads to Dutch Disease in Turkey's economy.

\section{DATA AND METHODOLOGY}

In the study, the annual data belonging to the variables of Consumer Price Inflation (CPI) and Imports between the years 2003-2018 is used. Empirical analysis has been executed by using SPSS (22) Pearson's Test technique and Regression 
Analysis. Whether there is a relationship between two or more variables, the direction and strength if the relationship exists is found by "correlation analysis". If one of the variables changes and the other shows a change, "regression analysis" is performed.

\subsection{Correlation Analysis}

The hypothesis ' 0 ' and one or two-way alternative hypotheses in correlation analyses of SPSS are as follows.

$\mathrm{H}_{0}: \mathrm{p}=0$ (correlation coefficient between two variables is zero)

$\mathrm{H}_{1}: \mathrm{p}<0$ (there is negative correlation between two variables) (one-way)

$\mathrm{H}_{1}: \mathrm{p}>0$ (there is positive correlation between two variables) (one-way)

$\mathrm{H}_{1}: \mathrm{p} \neq \mathrm{O}$ (correlation coefficient between two variables is different from zero) (two-way)

SPSS, Correlation Significance (Sig.) values are as follows;

If Sig. $>, 05, \mathrm{H}_{0}$ is agreed. There isn't significant correlation between the variables.

If $\mathrm{Sig} .<, 05, \mathrm{H}_{0}$ is rejected. There is significant correlation between the variables (Bursal, 2017:108).

Before Pearson's Test, we should research whether the variables provide the normal distribution hypothesis in significance level of 0,05 and the existence of extreme values.

Table 1: Test of Normality and Hypothesis of Normality

\begin{tabular}{cccccc}
\hline \multicolumn{2}{c}{ Kolmogorov-Smirnova $^{\text {S }}$} & \multicolumn{3}{c}{ Shapiro-Wilk } \\
\hline Statistic & df & Sig. & Statistic & df & Sig. \\
\hline 178 & 16 &, 186 &, 927 & 16 &, 221 \\
\hline
\end{tabular}

Note: a. Lilliefors Significance Correction

If $n<50$, the result of Shapiro-Wilk Test is evaluated. Table Sig.: $(p=0,221)$. According to this, since $p>0,05$, the distribution of variables provides the normal distribution condition in significance level of 0,05.

\subsection{Extreme Value Analysis}

The other condition to be tested assuming the validity of the hypothesis of normal distribution is to ascertain the extreme values which distort the normal distribution of variable.

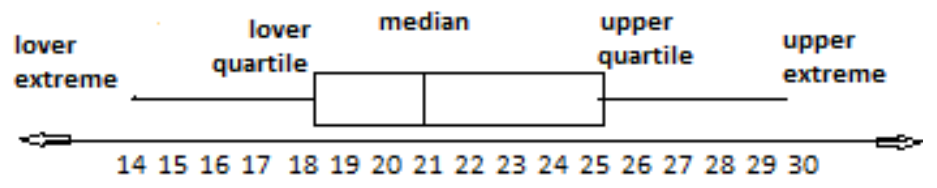

A box and whisker plot is a way of summarizing a set of data measured on an interval scale. It is often used in explanatory data analysis. This type of graph is used to show the shape of the distribution, its central value, and its variability.

In a box and whisker plot:

- the ends of the box are the upper and lower quartiles, so the box spans the interquartile range

- the median is marked by a vertical line inside the box

- the whiskers are the two lines outside the box that extend to the highest and lowest observations (Statistics Canada, 2019) 
Figure 1: Box Plot

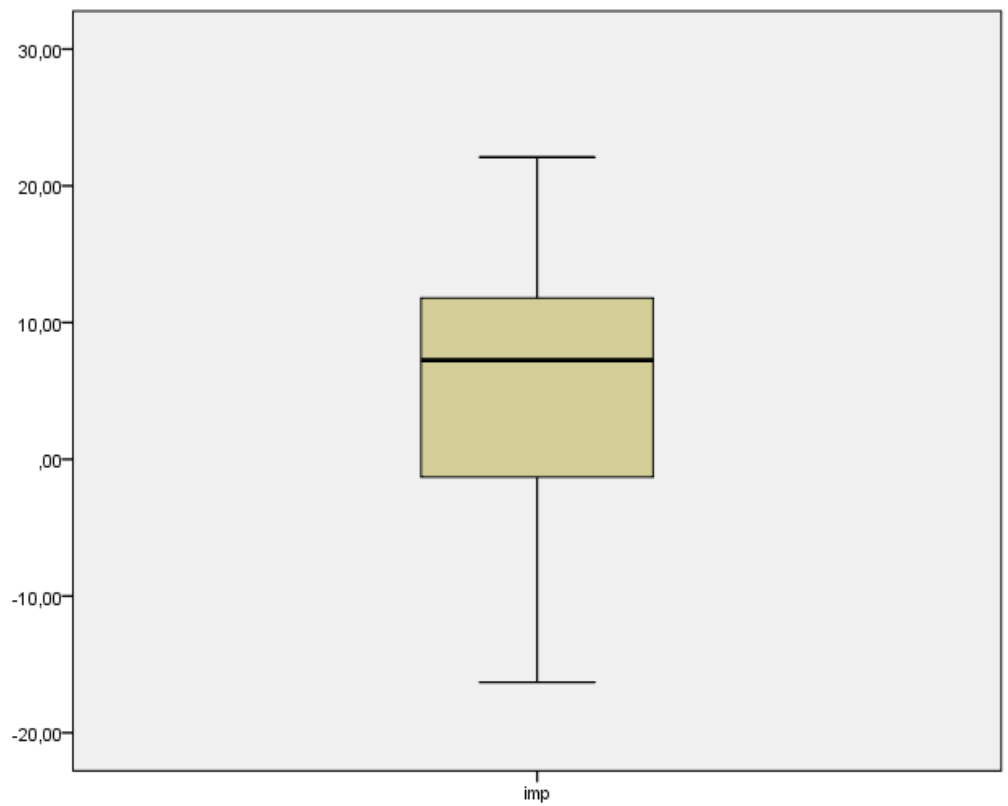

It is seen that there isn't any outliner in data distribution when Box Plot is examined.

\subsection{Calculating Pearson's Correlation Coefficient and Regression Analysis}

The word correlation is used in everyday life to denote some form of association. We might say that we have noticed a correlation between foggy days and attacks of wheeziness. However, in statistical terms we use correlation to denote association between two quantitative variables. We also assume that the association is linear, that one variable increases or decreases a fixed amount for a unit increase or decrease in the other. The other technique that is often used in these circumstances is regression, which involves estimating the best straight line to summarise the association (The BMJ, 2019).

Table 2: Correlation between Inflation and Imports for the years 2003-2018 (Pearson)

\begin{tabular}{cccc}
\hline & & imp & Tufe \\
\hline \multirow{3}{*}{$\operatorname{imp}$} & Pearson Correlation & 1 &, $634^{* *}$ \\
\cline { 2 - 4 } & Sig. (2-tailed) & &, 008 \\
\cline { 2 - 4 } & $\mathbf{N}$ & 16 & 16 \\
\hline \multirow{2}{*}{ tufe } & Pearson Correlation &, $634^{* *}$ & 1 \\
\cline { 2 - 4 } & Sig. (2-tailed) &, 008 & \\
\cline { 2 - 4 } & $\mathbf{N}$ & 16 & 16 \\
\hline
\end{tabular}

**. Correlation is significant at the 0.01 level (2-tailed).

In Table 2, Pearson's Correlation Coefficient of imports (imp) and inflation (CPI) becomes ( $r=634, p=, 008)$. According to the coefficient values which is calculated, because significance value is $p<, 01, H_{0}$ hypothesis for two variables is rejected and it can be stated that there is a significant correlation between imports (imp) and inflation (CPI).

Accordingly, Pearson's Correlation Coefficient is reported in this way;

$r=, 634 ; n=16 ; p=, 008$

With the purpose of testing the correlation between the variables with a different method, Scatter Plot and regression line are drawn with SPSS. Accordingly, the figure below is obtained. 
Figure 2: Scatter Plot and Regression Line

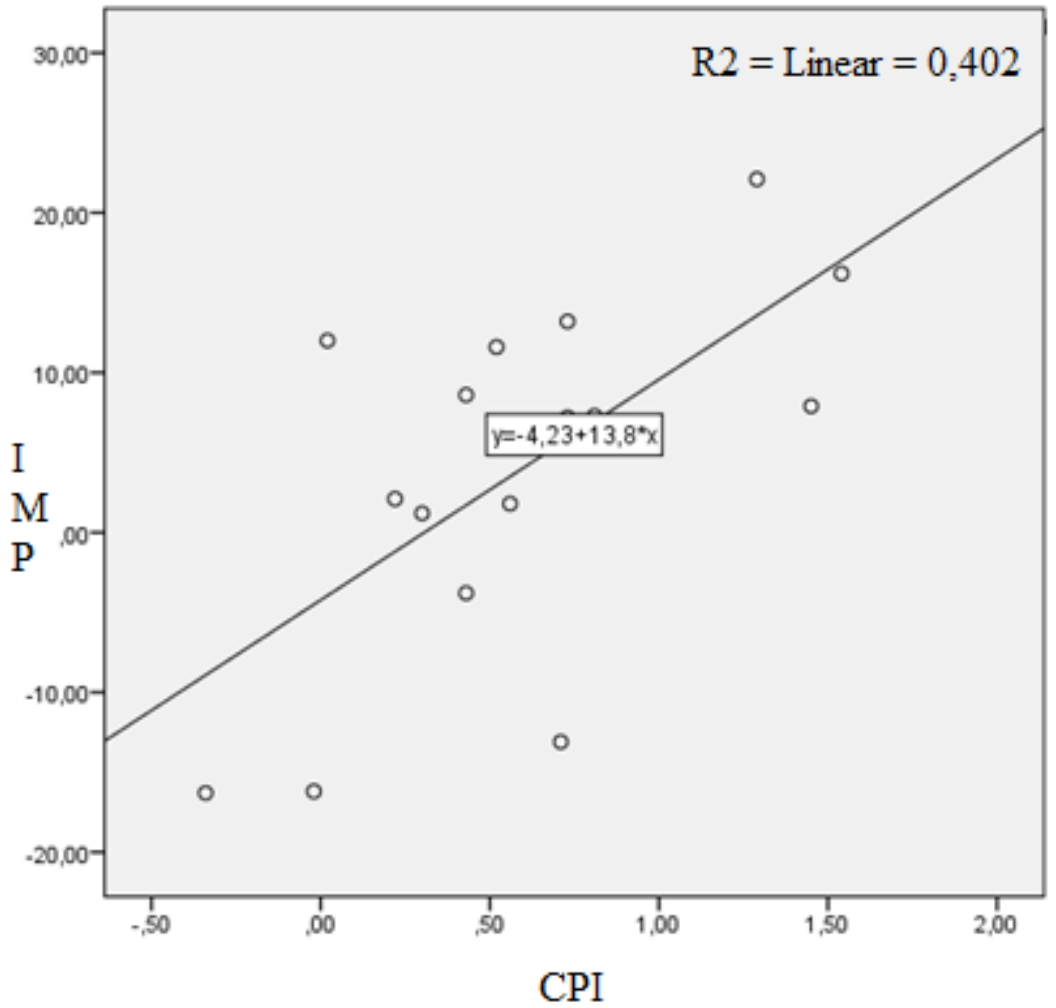

In Figure 2, regression equation of our model becomes $y=4,23+13,8^{*} X$. Accordingly, it is possible to say that there is a weak but positive correlation between the variables. Thereby, according to the results of both correlation and regression line analyses; in both situations, there is a positive linear relationship between the variables. Namely, while one of them increases, the other one increases; while one of them decreases, the other one also decreases. If we investigate this situation through the value of money, the inverse relationship between the two variables will be confirmed. In another saying, the increase of inflation means that the national currency depreciates; so that, according to the results obtained from our model, in such a situation (in case of increasing the inflation) imports increase as well. Similarly, the decrease of inflation means that the national currency appreciates; so that, according to the results of our analysis, in case of appreciation of national currency (in case of the decrease of inflation) imports decrease as well. This too proves that "Dutch Disease" is out of the question for Turkey's economy in the specified period.

The Figure below which is formed in accordance with the data of Imports and Consumer Price Index taken from the resources of Turkish Statistical Institute and the Central Bank of the Republic of Turkey supports this situation. If we take them into consideration, the difference between the two variables has gradually gotten larger especially since 2010 . In this period, the depreciation of TL has become much higher in comparison with the increase in imports. Whereas, by the definition of Dutch Disease, we anticipated the increase of imports with the condition of the appreciation of national currency. This, too, reveals that the speculative approaches in this issue are unfair. 
Figure 3: 2003-2018 Import and CPI in Turkey CPI (Consumer Price Index)

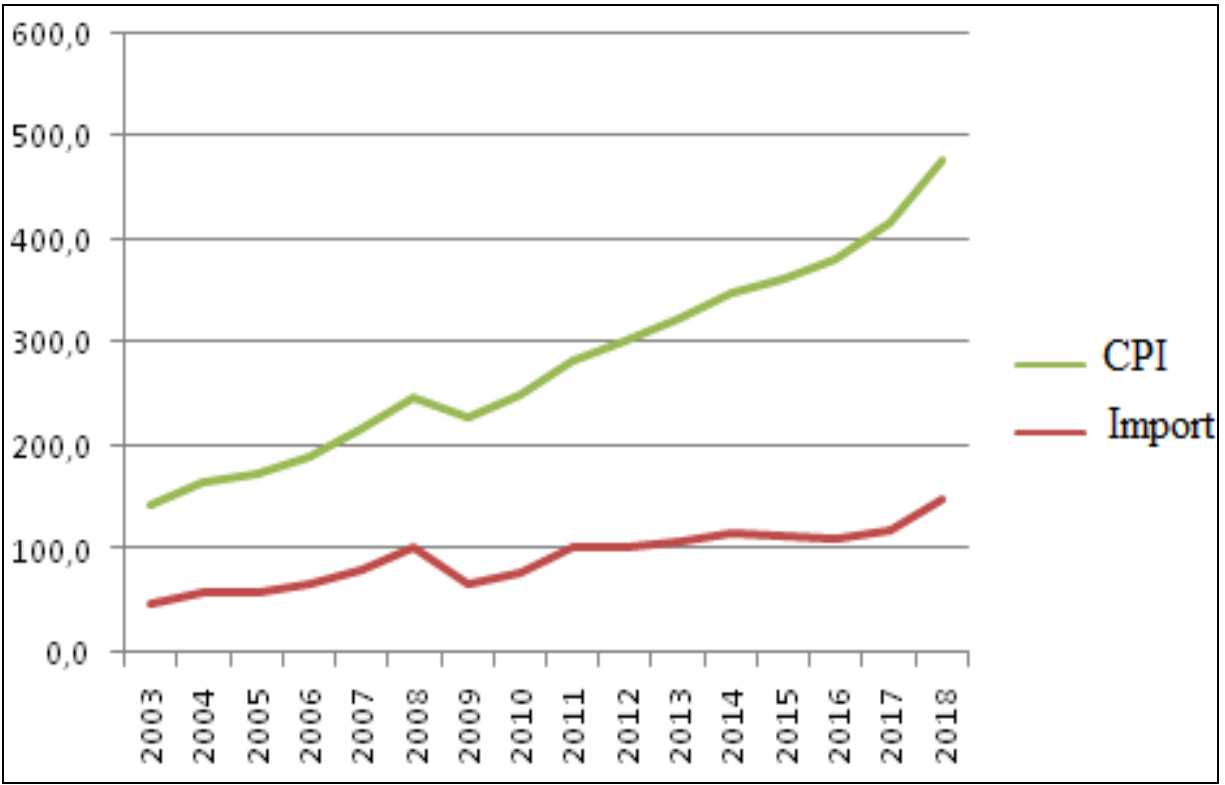

\section{CONCLUSION}

In 1960s, Holland's economy gained acceleration by means of the natural gas reserves in Holland and a positive atmosphere is obtained. With the increase of production and exportation of natural gas, Dutch Florin appreciates. With the national currency appreciation, imports become cheaper and domestic production becomes more expensive in the course of time. With the increase of domestic production costs, imports become more attractive for Dutch producers, therefore imports increase. With the decrease of production on one hand and the increase of external dependence on the other hand, the positive atmosphere which is caught by the discovery of natural gas sources soon becomes reversed.

The adverse circumstances which have been experienced in Turkey's economy recently are attributed to 'Dutch Disease'. The positive atmosphere which was experienced in the economy and the appreciation of national currency previously and then the rise of the inflation to double-digits and the increase of imports have been effective for this metaphor. Within this context, it has been desired to test the availability of 'Dutch Disease' in Turkey's economy for the specified period. For this, we used the annual data belonging to the variables of Consumer Price Inflation (CPI) and Imports between the years 20032018. According to the findings obtained by using SPSS (22) Pearson's Test technique for Empirical Analysis, contrary to what is alleged, there is no connection of the adverse circumstances which have been experienced in Turkey's economy recently to 'Dutch Disease'.

For the Dutch Disease to be able to occur, the currency used as medium of exchange is required to be convertible. Because the national currencies of the developing countries such as Turkey are not convertible, the national currency appreciates only within the boundaries of the country. Whereas the appreciation of the national currencies of countries whose currency is convertible like Holland can stand out both internally and externally. Within this context, the adversity which has been experienced in Holland's economy derives from the decrease of production. This isn't directly associated with the value of Florin. However, the decrease of the production in Turkey is associated with imports not becoming cheaper but on the contrary becoming more expensive. Namely, while TL depreciates on one hand, imports become more expensive on the other hand. Imports becoming more expensive derives from abroad to a great extent. The primary reason is that the increase in the prices of notably petroleum, natural gas and other imported energies in the world markets increases the input costs. 


\section{REFERENCES}

Adenauer, I., Vagassky, L. (1998). Aid and the Real Exchange Rate: Dutch Disease Effects in African Countries, Intereconomics: Review of European Economic Policy. 33(4):177-185.

Akça, E.E., Bal, H. (2017). International Labor Income and Dutch Disease: A Panel Data Analysis for Selected Countries, Eskişehir Osmangazi University Journal of Economics and Administrative Sciences. 12(2):49- 64.

Akçacı, T., Karaata, A. (2014).The Paradoxical Effect of International Funds in Turkey: Dutch Disease, SESSION, International Conference On Eurasian Economies.

Altınok, S., Çetınkaya, M. (2003). Development and Devaluation in Turkey Applications And Results, Selcuk University Journal of Social Sciences Institute. 9, 47-64.

Arı, A., Özcan, B. (2012). Dutch Disease: An Application on Developing Countries, Socioeconomics. 2, 153-172.

Balaylar, A.N. (2011). The Relationship of Real Manufacturing Industry, Socioeconomics. 2, 137-160.

Başoğlu, U. (2000).Financial Liberalization and International Portfolio Investment, Balıkesir University Institute of Social Sciences Journal. $3(4): 88-89$

Botta, A., Godin, A., Missaglia, M. (2015). Finance, Foreign Direct Investment, and Dutch Disease: The Case of Colombia, Levy Economics Institute Working Paper, 15-853.

Brahmbhatt, M., Otaviano, C., Ekaterina, V. (2010). (2019, June 12). Dealing with Dutch Disease, Economic Premise. The World Bank, http://siteresources.worldbank.org/INTPREMNET/Resources/EP16.pdf retrieved from address.

Bursal, M. (2017). SPSS Basic Data Analysis. Ankara: Arı Spreading.

Central Bank of the Republic of Turkey (CBRT). (2019, June 12). Inflation Report. https://www.CBTR.gov.tr retrieved from address.

Coşkun, M., Taylan, A.S. (2009).Does The Exchange Rates Movements Affect Export And Import Volume? Turkey Case: 1999-2007, Journal of Accounting and Finance. 42, 157-168.

Değırmen, S. (2008). Orthodox Economics Policies in Turkey and the IMF: Inflation Reports, Society and Democracy. 2(2): 133-148.

Destek, M.A., OKUMUS, I., YILDIRIM, A. (2017). Effects of Dutch Disease on Agricultural Value Added: Findings for Azerbaijan, Kazakhstan, Kyrgyzstan and Uzbekistan. Bilig. 83, 225-239.

Durmuş, H. (2018). Targeting Inflation In Turkey: An Evaluation Of The Implicit And Explicit Inflation Periods, Journal of Social Sciences Institute. 11,181-201.

Eğılmez, M. Dutch Disease. (2019, July 19). ttp://www.mahfiegilmez.com/2019/03/hollanda-hastalg-ve-turkiye.html\#more

Güney, P. Ö., Ceylan, İ. M. (2014). Inflation Targetting: The Case of Turkey, HU Journal of the Faculty of Economics and Administrative Sciences. 32(1): 143-164.

Hyder, Z. and Shah, S. (2004). Exchange Rate PassThrough to Domestic Prices in Pakistan, State Bank of Pakistan Working Paper, 04-5.

Fisher, I. (1911). (2019, July 21). The Purchasing Power of Money, its Determination and Relation to Credit, Interest and Crises. The Online Library of Liberty. https://eet.pixel-online.org/files/etranslation/original/Fisher retrieved from address.

Karaçor, Z., Gerçeker M. (2012). Real Exchange Rate and Foreign Trade, Sample Of Turkey (2003 -2010), Selcuk University, Faculty of Economics and Administrative Sciences, Journal of Social and Economic Research. No.23: 289-312.

Karagöl, V., Erdoğan, M. (2017). Determinants of Current Account Deficit and Current Practices for Public Policy in Turkey's Economy. Ulakbilge. 5(10): 353-381.

Kenell, L. (2008). Dutch Disease and Tourism The Case of Thailand, Bachelor diss., Supervisor: Yves Bourdet, Department of Economics, Lund University.

Kesbır, M. (2018).2001 State of the Banking Sector in Turkey after the Crisis, Structural Reforms and Developments in Recent Years, Bitlis Eren University Journal of Academic Projection. 3(2):1-19.

Kundak, S., Aydoğuş i. (2018). Analysis of The Turkish Manufacturing Industry's Dependence on Imports, Gaziantep University Journal of Social Sciences. 17(1): 252-266.

Mercan, M., Göçer, i. (2014). The Risk of Dutch Disease in the Central Asian Turkish Republics: An Empirical Analysis, H.Ü. Journal of Faculty of Economics and Administrative Sciences. 32(2): 251-274. 
Nchor, D., Pavel, K., Strelec, L., Samuel A.D. (2015). The New Oil Sector And The Dutch Disease: The Case Of Ghana, Acta Universitatis Agriculturae Et Silviculturae Mendelianae Brunensis, 63(6): 2035-2041. on June 02, 2019 https://doi.org/10.11118/actaun201563062035 retrieved from address.

Okur, A. (2015). Economic Stability On The Effects Of Flexible Exchange Rate Policy Followed In Turkey, Management and Economics. 1(2): 43-52.

Okutan, Ş. (2015).2000-2014 Macroeconomic Effects of Fiscal Deficit and the Year of Turkey's Economy, International Journal of Social Sciences and Education Research. 1(4): 1154-1168.

Ordu, C. F. (2013). Srelatıonshıp Between Exchange Rates And Foreıgn Trade: Case Of Turkey, PhD diss., University of Adnan Menderes, Graduate School Of Social Sciences, Department Of Economics.

Orhan, O. Z., Nergiz, E. (2014). Turkey's Current Account Deficit Problem and Its Effects on the European Union Accession, iGÜSBD. (1)1: 138-158.

Öztürk, S., Usanmaz, D. (2018). In Turkey, Inflation Targeting Strategy Implementation Process Analysis: Sampling Years 2002-2016, Ömer Halisdemir University Faculty of Economics and Administrative Sciences Journal. 11(4): 93-105.

Pereira,L.C. B. (2013).The value of the exchange rate and the Dutch Disease, Brazilian Journal of Political Economy. 33(3): $371-387$.

Ramirez- C.L. R. (1985). Currency Substitution in Argentina, Mexico and Uruguay, IMF Staff Papers, 32-4.

Rojas-Suarez, L. (1992). Currency Substitution and Inflation in Peru. IMF Working Paper.92-33.

Savastano, A. M. (1996). Dollarization in Latin America: Recent Evidence and Some Policy Issues, IMF Working Paper, $96-4$.

Seyidoglu, H. (2007). International Economics Theory Policy and Practice, 16th Edition, Istanbul: Güzem Can Publications.

Stanford, J. (2012). A Cure for Dutch Disease: Active Sector Strategies for Canada's Economy, Alternative Federal Budget, Sector Development Policy, Technical Paper 1-11.

Sungur, O. (2015).In 2000 After Turkey's Economy: Growth, Inflation, Unemployment, Debt and Foreign Trade Developments, Society and Democracy.9, 243-269.

Sy, M. and Tabarraei, H. (2018). (2019, Juni 17). Capital inflows and exchange rate in LDCs: The Dutch Disease Problem Revisited, HAL Id: halshs-00574955, https://halshs.archives-ouvertes.fr/halshs-00574955, retrieved from address.

Statistics Canada (2019), Constructing Box And Whisker Plots, https://www150.statcan.gc.ca/n1/edu/power-pouvoir/ch12/5214889eng.htm retrieved from address.

Şimşek, G.(2017). Obstacles In Front Of Human Capital And Human Capital Formation Capital Policy Development Process Of Productive In Turkey, Political Economic Theory. 1(2): 79-117.

Taşar, M. O. (2010). Turkey's Transition to Strong Economy Program and Analysis of Macro-Economic Impacts, Nigde University Journal of Business Administration. 3(1): 76-97.

Tapşın, G., Karabulut, A.T. (2013). The Causal Relationship Among Real Exchange Rate, Import And Export: The Case Of Turkey, Akdeniz University Faculty of Economics and Administrative Sciences Journal, No.26: 189-204.

Taymaz, E., Voyvoda, E., (2015). Towards 2023: Industrial, Structural Transformation and Industrial Policies. Economics Business Finance. 30(350): 25-62.

The BMJ, Correlatıon and Regressıon. https://www.bmj.com/about-bmj/resources-readers/publıcatıons/statıstıcs-square-one/11correlatıon-and-regression retrieved from address.

Turkish Statistical Institute (TUIK). (2019, June 13). Foreign Trade Statisticshttps, www.tuik.gov.tr retrieved from address.

Ünsal, M.E. (2005). International Economics,Theory, Politics and Open Economy Macroeconomics, 1th Edition, Ankara: İmaj Publishing.

Uğurlu, E., Saraçoğlu, B. (2010). Inflation Targeting and Inflation Forecasting in Turkey, Dokuz Eylül University Faculty of Economics and Administrative Sciences Journal. 25(2):57-72

Weijermars, R., Luthi, S. M. (2011). Dutch Natural Gas Strategy: Historic Perspective and Challenges Ahead, Netherlands Journal of Geosciences, Geologie en Mijnbouw. 90(1): 3-14.

Wicksell, K. (1962). Interest And Prices Geldzins und Guterpreise A Study Of The Causes Regulating The Value Of Money, Translated by R.F. Kahn, Newyork: Printed in The United States Of America By Sentry Press.

Yiğit, M. (2001). Dutch Disease, Dumlupinar University Journal of Social Sciences.5, 124-136. 